\title{
Grazing intensity and stocking methods on animal production and methane emission by grazing sheep: Implications for integrated crop-livestock system
}

\author{
Jean Victor Savian ${ }^{\mathrm{a}, *}$, Armindo Barth Neto ${ }^{\mathrm{a}, \mathrm{e}}$, Diego Bitencourt de David ${ }^{\mathrm{b}}$, \\ Carolina Bremm $^{\mathrm{b}}$, Radael Marinho Três Schons ${ }^{\mathrm{a}}$, Teresa Cristina Moraes Genro ${ }^{\mathrm{d}}$, \\ Glaucia Azevedo do Amaral ${ }^{\mathrm{b}}$, José Gere ${ }^{\mathrm{c}}$, Concepta Margaret McManus ${ }^{\mathrm{a}}$, \\ Cimélio Bayer ${ }^{\mathrm{a}}$, Paulo César de Faccio Carvalho ${ }^{\mathrm{a}}$ \\ a Grazing Ecology Research Group, Faculty of Agronomy, Federal University of Rio Grande do Sul, Avenida Bento Gonçalves, 7712, Agronomia, Caixa Postal \\ 776, CEP 91501-970, Porto Alegre, RS, Brazil \\ b State Foundation of Agricultural Research (FEPAGRO), Rua Gonçalves Dias, 570, Bairro Menino Deus, Porto Alegre, RS, Brazil \\ ${ }^{\mathrm{c}}$ National University of Central State of Buenos Aires, Pinto 399, Tandil, 7000, Argentina \\ d Brazilian Agricultural Research Corporation (EMBRAPA Pecuária Sul), Bagé, RS, Brazil \\ e Federal University of Paraná, Rua dos Funcionários, 1540, Juvevê, Caixa Postal 19061, CEP 81531-990, Curitiba, PR, Brazil
}

\section{A R T I C L E I N F O}

\section{Article history:}

Received 3 April 2013

Received in revised form 15 January 2014

Accepted 10 February 2014

Available online 11 March 2014

\section{Keywords:}

Greenhouse gases

Herbage allowance

Herbage intake

Italian ryegrass

Lactating ewes

Lambs

Sulfur hexafluoide

\begin{abstract}
A B S T R A C T
Among the various sources with a potential negative impact on the environment, methane $\left(\mathrm{CH}_{4}\right)$ emissions from livestock origin have been highlighted as important for the agricultural sector. Research to mitigate $\mathrm{CH}_{4}$ emissions and understand how integrated crop and livestock production systems may contribute to the reduction of greenhouse gases, is essential for the development of public policies for environmental preservation. We hypothesized that combinations of stocking methods and grazing intensities provokes differences in the quantity and quality of herbage ingested, thus altering animal production and $\mathrm{CH}_{4}$ emissions by the grazing animal. Experiments were carried out in 2011 (Experiment 1) and 2012 (Experiment 2), when the production of pasture and $\mathrm{CH}_{4}$ emissions from sheep were studied in a system that integrates soybean (Glycine max. (L.) Merr.) and maize (Zea mays L.) in the summer/autumn, in rotation with Italian ryegrass (Lolium multiflorum Lam.) in winter/spring. Two stocking methods (continuous or rotational) and two grazing intensities (herbage allowance: moderate and low, 2.5 and 5 times the potential daily dry matter intake, respectively) in a randomized complete block design with three replicates were studied. Lambs were used in the first experiment, while lactating ewes (all with a single lamb) were used in the second experiment. Average daily gain (ADG) of lambs was greater $(P<0.05)$ in continuous than in rotational stocking, regardless of grazing intensity ( 150 vs. $89 \mathrm{~g} \mathrm{day}^{-1}$ and 241 vs. $209 \mathrm{~g} \mathrm{day}^{-1}$ in Experiments 1 and 2, respectively). Ewe ADG did not differ $(P>0.05)$ between treatments. Live weight gain per hectare (LWGHA) showed the same response in both experiments, with greater LWGHA in moderate grazing intensity $(P<0.05)$. In Experiment 1 , the dry matter intake (DMI) was on average $21 \%$ greater $(P<0.05)$ for continuous stocking than rotational stocking ( $1345 \mathrm{~g} \mathrm{day}^{-1}$ vs. $1075 \mathrm{~g} \mathrm{day}^{-1}$, respectively), while in Experiment 2, no differences $(P>0.05)$ between stocking methods and grazing intensities were observed $\left(1673 \pm 83 \mathrm{~g} \mathrm{day}^{-1}\right)$. The $\mathrm{CH}_{4}$ emissions per animal did not differ $(P>0.05)$ among treatments in both experiments $(22.7 \pm 1.0$ and $39.9 \pm 1.3 \mathrm{~g} \mathrm{day}^{-1}$, Experiments 1 and 2 , respectively), but when expressed in $\mathrm{g} \mathrm{CH}_{4} \mathrm{~kg} \mathrm{ADG}^{-1}$ emissions were on average 35 and $15 \%$ greater (Experiments 1 and 2, respectively) $(P<0.05)$ under rotational than continuous stocking, independent of grazing intensity (171 vs. $263 \mathrm{~g} \mathrm{CH}_{4} \mathrm{~kg} \mathrm{ADG}^{-1}$
\end{abstract}

\footnotetext{
Abbreviations: ADF, acid detergent fiber; ADG, average daily gain; C, carbon; CP, crude protein; DHA, daily herbage accumulation; DM, dry matter; DMI, dry matter intake;

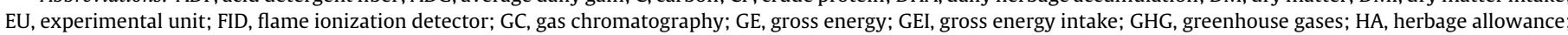

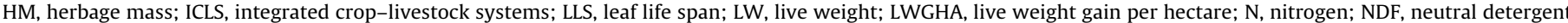
fiber; OM, organic matter; SH, sward height; SR, stocking rate; THP, total herbage production.

* Corresponding author. Tel.: +55 513308 7402; fax: +55 4133505601 .

E-mail address: jvsavian@gmail.com (J.V. Savian).
} 
and 171 vs. $202 \mathrm{~g} \mathrm{CH}_{4} \mathrm{~kg} \mathrm{ADG}^{-1}$ in Experiments 1 and 2, respectively). Stocking method was more important than grazing intensity in determining methane production by grazing sheep. Continuous stocking was the most efficient grazing management in reducing methane emissions per unit animal production.

(c) 2014 Elsevier B.V. All rights reserved.

\section{Introduction}

Agriculture contributes $13.5 \%$ of global emissions of greenhouse gases (GHG) (IPCC, 2007). About 50\% of $\mathrm{CH}_{4}$ and $60 \% \mathrm{~N}_{2} \mathrm{O}$ are from anthropogenic sources (Smith et al., 2007), while livestock contributes $18 \%$ to global GHG emissions (FAO, 2006). In Brazil, according to data from the Second National Communication to the convention - the United Nations Framework on Climate Change (2010), the agricultural sector is most responsible for emissions of $\mathrm{CH}_{4}$ (70\% in 2005), mainly due to ruminant livestock (63\% of total $\mathrm{CH}_{4}$ emitted in Brazil).

Among the various technologies that are being developed and improved to mitigate GHG emissions, FAO (2010) highlights integrated crop-livestock systems (ICLS) due to a lower input use, adequate protection of soil and water resources, and contribution to increased sequestration of atmospheric $\mathrm{C}$, whilst increasing biodiversity and resilience. In Brazil, farmers have resisted this technology due to uncertainties regarding the impact of animals on soil physical properties and crop yield. However, research results have shown that ICLS can actually improve the physical, chemical and biological properties of the soil (Carvalho et al., 2010) and increase $\mathrm{C}$ stocks depending on grazing intensity (Franzluebbers, 2010).

Despite the benefits of ICLS, its actual potential of GHG mitigation and $C$ balance remains unclear. In general, the crop component under no-till is considered a $C$ sequestration phase due to no-till environmental friendly recognized features (Holland, 2004). Concerning the pasture phase, however, there is concern because $C$ balance is highly dependent on grazing management (Carvalho et al., 2010). Depending on the grazing intensity and its spatiotemporal distribution, pasture production (sequestration) and animal production (emissions) can be highly variable. For example, Hammond et al. (2013) reported emission on a daily basis ranging from 12 to $32 \mathrm{~g} \mathrm{CH}_{4}$ sheep ${ }^{-1}$ depending on herbage allowance. According to Phetteplace et al. (2001), intensive grazing can reduce $\mathrm{CH}_{4}$ emission per unit production by approximately $10 \%$.

Regarding pasture condition, Wims et al. (2010) quantified the effect of herbage mass ( $\left.1000 \mathrm{~kg} \mathrm{DM} \mathrm{ha}^{-1} \mathrm{vs.} 2200 \mathrm{~kg} \mathrm{DM} \mathrm{ha}^{-1}\right)$ at the entry of the animals onto the pasture on the production of $\mathrm{CH}_{4}$ and found that greater herbage mass increased daily $\mathrm{CH}_{4}$ emissions per cow $(+42 \mathrm{~g})$, per $\mathrm{kg}$ of milk produced $(+3.5 \mathrm{~g})$ and per $\mathrm{kg}$ of herbage intake $(+3.1 \mathrm{~g})$. These results suggest that lower herbage mass has greater forage quality with consequent reduction in emission of $\mathrm{CH}_{4}$, illustrating how grazing management can influence $\mathrm{CH}_{4}$ emissions.

Consequently, grazing management seems pivotal in determining the final C balance of ICLS. However, there is no reference about how stocking methods could influence $\mathrm{CH}_{4}$ emissions, and how potential interactions between grazing intensities and stocking method could influence emissions in ICLS.

In this context, this study focused on $\mathrm{CH}_{4}$ emissions of the pasture cycle in ICLS where Italian ryegrass was rotated with soybean or maize. We hypothesized that combinations of stocking method and grazing intensity provokes a difference in the quantity and quality of herbage ingested, thus altering animal production and $\mathrm{CH}_{4}$ emissions by the grazing animal. Results would support grazing management aiming to minimize $\mathrm{CH}_{4}$ emissions in the pasture cycle and maximize the possibility to reach favorable $C$ balance in ICLS.

\section{Materials and methods}

\subsection{Experimental conditions}

The experiment was conducted at the Federal University of Rio Grande do Sul (UFRGS), in Eldorado do Sul, Rio Grande do Sul State, Brazil (latitude $30^{\circ} 05^{\prime} \mathrm{S}$ and longitude $51^{\circ} 39^{\prime} \mathrm{W}$ and altitude of $46 \mathrm{~m}$ ), in an area of Italian ryegrass (Lolium multiflorum Lam.) pasture. The climate is subtropical humid "Cfa" according to the Köppen classification. The soil at the experimental site was classified as a Typic Paleudult (USDA, 1999) with $15 \%$ clay.

The experimental area consisted of an ICLS established in 2003. During the summer/autumn there were two no-till cropping systems: soybean (Glycine max. (L.) Merr.) or maize (Zea mays L.). After harvesting crops in autumn and during winter, Italian ryegrass established by self-seeding supported by the seed bank of previous rotation years, and animals began the stocking cycle that lasted until the next cropping phase.

The experimental data collected in this study refers to an Italian ryegrass pasture phase of two years: 2011 (Experiment 1) and 2012 (Experiment 2). In both experiments, Italian ryegrass pasture was fertilized with $75 \mathrm{~kg} \mathrm{~N} \mathrm{ha}^{-1}$ as urea just after summer crop harvest (Experiment 1: May 25th, 2011 and Experiment 2: June 1st, 2012) and another $75 \mathrm{~kg}$ of $\mathrm{N} \mathrm{ha}^{-1}$ later in the stocking cycle (Experiment 1: September, 2nd, 2011 and Experiment 2: August, 30th, 2012).

The experimental design was a randomized complete block with three replicates (paddocks). The experiment was arranged in a two-level factorial design, with two stocking methods (continuous and rotational) and two grazing intensities for sheep: herbage allowance of 2.5 and 5 times (namely moderate and low, respectively) the potential daily dry matter intake (DMI) according to the NRC (1985).

The experimental area of 3.2 hectares (ha) was divided into 12 paddocks, ranging from 0.23 to 0.31 ha. Each paddock as experimental unit (EU) received three tester-animals (permanent animals that remained throughout the experimental period) and a variable number of animals periodically adjusted to maintain the desired herbage allowance ("put-and-take" method, Mott and Lucas, 1952). The experimental animals in Experiment 1 were Texel $\times$ Ile de France growing lambs, with an average age of 11 months and weighing $35 \pm 4 \mathrm{~kg}$. In Experiment 2, lactating Texel $\times$ Suffolk single-bearing ewes were used, all multiparous and weighting $59 \pm 6 \mathrm{~kg}$.

\subsection{Sward management and herbage sampling}

The leaf life span (LLS) is a criterion associated to pasture use efficiency (how many days - in thermal time - a leaf remains available to grazing before senescing) and was used to determine the interval of each stocking rate adjustment to maintain predefined herbage allowance. This interval corresponds to stocking cycles described below. Data from Pontes et al. (2003) in the same experimental area were used: $500^{\circ} \mathrm{C} /$ leaf for the period from June to August, and $410^{\circ} \mathrm{C} /$ leaf for the period from September to November. Therefore, the number of days of each stocking cycle was derived as follows: 36, 36, 28 and 22 days in Experiment 1 and 36, 28, 28 and 22 days in Experiment 2 (differences due to different periods of the year). In 
2011, the grazing period began on June 18th and the animals were removed on October 24th, totaling 122 days. In Experiment 2 the grazing period was of 114 days, beginning on July 11 th and ending on November 1st, 2012.

At the beginning of each stocking cycle, herbage mass (HM) was sampled at ground level and estimated in six areas of $0.25 \mathrm{~m}^{2}$ per EU. The herbage was dried at $55^{\circ} \mathrm{C}$ for $72 \mathrm{~h}$ and weighed. Then, morphological separation (leaf blades, stem + sheath, inflorescences and dead material) was carried out from a composite sample of each EU.

The daily herbage accumulation (DHA) rate for each stocking cycle was estimated in continuous stocking paddocks by four grazing exclusion cages per EU (Klingman et al., 1943). In rotational stocking paddocks, four samples from $0.25 \mathrm{~m}^{2}$ quadrats were obtained in the second grazing strip after animal grazing, and just before the animals entered the same strip again. The difference in the amount of dry matter (DM) between samplings was considered as the herbage accumulated. Rate at DHA was obtained by dividing the amount of accumulated herbage by the number of days between cuts. These measurements were performed in each stocking cycle, with drying and collection procedures similar to those described for HM.

The herbage allowance (HA, \% LW) was calculated according to the following equation: $\mathrm{HA}(\% \mathrm{LW})=((\mathrm{HM} / n+\mathrm{DHA}) / \mathrm{SR}) \times 100$. Where: $L W=$ live weight, $H M=$ average herbage mass of each stocking cycle ( $\left.\mathrm{kg} \mathrm{DM} \mathrm{ha}^{-1}\right), n=$ number of days of stocking cycle, $\mathrm{DHA}=$ daily herbage accumulation $\left(\mathrm{kg} \mathrm{DM} \mathrm{ha}^{-1}\right), \mathrm{SR}=$ stocking rate of each stocking cycle $\left(\mathrm{kg} \mathrm{LWha}^{-1}\right)$. The total herbage production (THP; $\mathrm{kg} \mathrm{DM} \mathrm{ha}^{-1}$ ) was obtained by the sum of the initial HM (beginning of the experiment) with the DHA of each stocking cycle. In each $\mathrm{EU}$, sward height $(\mathrm{SH})$ was randomly measured at 150 points using a sward stick (Barthram, 1985).

Samples to address herbage chemical composition were obtained by hand-plucking (Johnson, 1978). Hand plucking was performed on the same days as the estimation of DMI. Considering the period of stay of two days in each strip for the rotational stocking, two simulations of grazing per EU were performed, one on each day and both during the afternoon. In other words, two samples on two consecutive days. This procedure was adopted for both stocking methods to reduce the possible effect of the day and time of the day on pasture chemical composition. After collection, samples were dried at $55^{\circ} \mathrm{C}$ for $72 \mathrm{~h}$, ground and used for the following analyses: DM at $105^{\circ} \mathrm{C}$ for $12 \mathrm{~h}$ (Easley et al., 1965); organic matter $(\mathrm{OM})$ by burning in a muffle furnace at $550^{\circ} \mathrm{C}(\mathrm{AOAC}$ method no. 22.010, and no. 7.010,1975), $\mathrm{N}$ content by the Kjeldahl method (AOAC methods 2036, 1960 and no. 2049, 1975), and this value multiplied by 6.25 to obtain the content of crude protein (CP), acid detergent fiber (ADF) and neutral detergent fiber (NDF) without the use of amylase (Van Soest and Robertson, 1985). The gross energy (GE) was determined by bomb calorimetry.

\subsection{Animal performance}

Stocking rate (SR, $\mathrm{kg} \mathrm{ha}^{-1}$ ) was calculated by summing the average weight of the tester animals and the weight of the put-and-take animals multiplied by the number of days they remained on pasture. The average daily gain (ADG, g animal ${ }^{-1} \mathrm{day}^{-1}$ ) was calculated as the difference between final and initial weights of tester animals, divided by the number of days in the experimental period. Animals were weighed after fasting from solids and liquids for approximately $12 \mathrm{~h}$. Live weight gain per hectare (LWGHA, $\mathrm{kg} \mathrm{ha}^{-1}$ ) was obtained by multiplying in animals ha ${ }^{-1}$, by ADG of the tester animals and by the number of grazing days. In Experiment 2, animal performance variables were respectively to the group of ewes with their lambs.

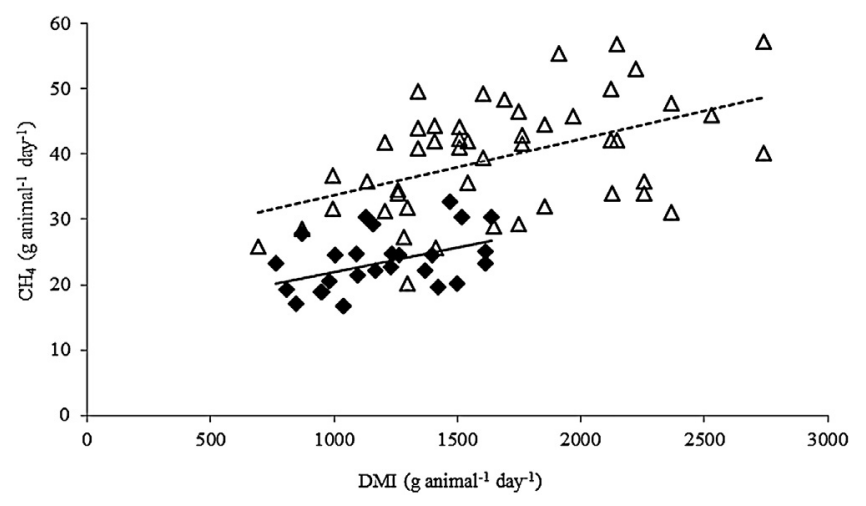

Fig. 1. Relationship between dry matter intake (DMI, ganimal ${ }^{-1} \mathrm{day}^{-1}$ ) and methane $\left(\mathrm{CH}_{4}\right)$ emission ( $\mathrm{g}$ animal ${ }^{-1} \mathrm{day}^{-1}$ ) by sheep grazing Italian ryegrass. Experiment $1(\diamond) y=0.007 x+14.6 ; R^{2}=0.18 ; \mathrm{MSE}=4.1 ; P=0.026$. Experiment $2(\triangle)$ $y=0.008 x+25.2 ; R^{2}=0.23 ; \mathrm{MSE}=7.6 ; P<0.001$.

\subsection{Herbage intake}

To determine daily DMI by sheep, three tester animals from each EU were utilized, using the n-alkanes technique. In Experiment 1 an evaluation of daily DMI was realized in the fourth stocking cycle. In Experiment 2, two evaluations for daily DMI (only on the ewes) were performed, one in the third and another in the fourth stocking cycle. The animals received pellets orally impregnated with dotriacontane $\left(C_{32}\right)$, twice a day at 08:00 and 16:00, totaling 10 days of dosing. From the fifth to the tenth day feces were collected "per rectum" concurrently with the dosage of the marker (n-alkane). To evaluate the concentration of n-alkanes in the pasture, samples were collected through hand plucking, according to Johnson (1978), as described previously. This simulation was performed simultaneously evaluating DMI, on the second and third days of feces collection.

The determination of $n$-alkanes present in the forage and feces followed the protocol proposed by Dove and Mayes (2006). The identification and quantification of n-alkanes were made by gas chromatography (GC) using a Shimadzu GC-2010 gas chromatograph equipped with a flame ionization detector (FID), a spool auto-sampler AOC-20S and a injector auto-injector AOC20i. The extracted n-alkanes were injected $(1 \mu \mathrm{L})$ into a column Restek Rtx ${ }^{\circledR}-5$ (30 m $0.25 \mathrm{~mm} \times 0.25 \mu \mathrm{m}$, absorbent composed by $5 \%$ diphenyl and 95\% polysiloxane dimitil). The carrier gas was $\mathrm{N}_{2}$ at a constant flow of $30 \mathrm{~mL} \mathrm{~min}^{-1}$. Temperature gradients were controlled for injector $\left(270^{\circ} \mathrm{C}\right)$ and column $\left(170^{\circ} \mathrm{C}\right.$ by $1 \mathrm{~min}$;

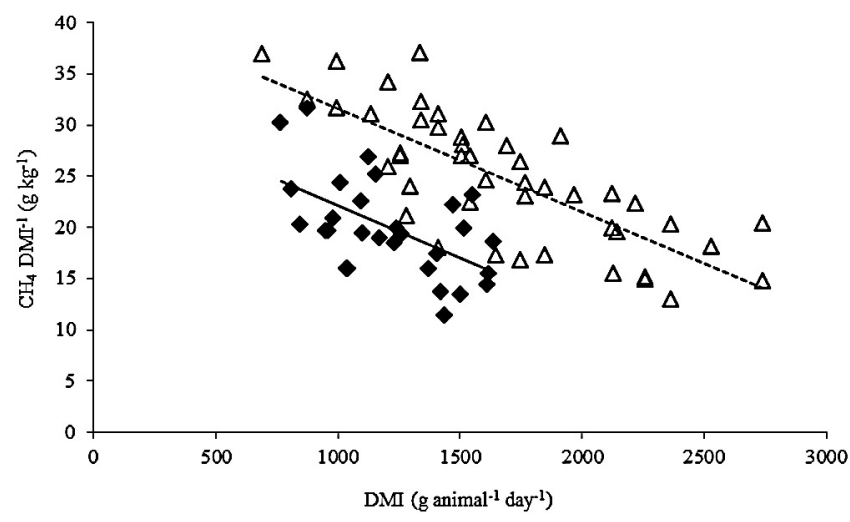

Fig. 2. Relationship between dry mater intake (DMI, g animal ${ }^{-1}$ day $^{-1}$ ) and methane $\left(\mathrm{CH}_{4}\right)$ emission $\left(\mathrm{gCH}_{4} \mathrm{~kg} \mathrm{DMI}{ }^{-1}\right)$ by sheep grazing Italian ryegrass. Experiment $1(\diamond) y=-0.011 x+32.7 ; R^{2}=0.33 ; \operatorname{MSE}=4.0 ; P=0.001$. Experiment $2(\triangle)$ $y=-0.010 x+41.8 ; R^{2}=0.59 ; \mathrm{MSE}=4.1 ; P<0.001$. 
Table 1

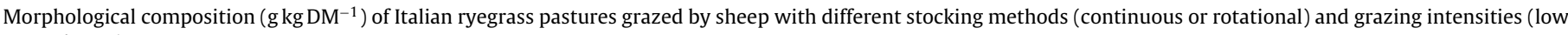
or moderate).

\begin{tabular}{|c|c|c|c|c|c|c|c|c|}
\hline \multirow[t]{2}{*}{ Variables } & \multicolumn{2}{|c|}{ Continuous } & \multicolumn{2}{|c|}{ Rotational } & \multirow[t]{2}{*}{ Mean \pm MSE } & \multirow[t]{2}{*}{$P_{\mathrm{I}}$} & \multirow[t]{2}{*}{$P_{\mathrm{M}}$} & \multirow[t]{2}{*}{$P_{\mathrm{I} \times \mathrm{M}}$} \\
\hline & Low & Moderate & Low & Moderate & & & & \\
\hline \multicolumn{9}{|l|}{ Experiment 1} \\
\hline Leaf blades & $202 b$ & $324 a$ & $256 b$ & $333 a$ & $279 \pm 15$ & $<0.001$ & 0.163 & 0.318 \\
\hline Stem + sheath & $608 a$ & $484 b$ & $610 a$ & $576 a$ & $565 \pm 13$ & $<0.001$ & 0.004 & 0.004 \\
\hline Dead material & $92 b$ & 139a & $55 c$ & $63 b c$ & $87 \pm 8.0$ & 0.006 & $<0.001$ & 0.044 \\
\hline Inflorescences & $100 a$ & $53 b$ & $89 a$ & $24 b$ & $67 \pm 8.0$ & $<0.001$ & 0.125 & 0.471 \\
\hline \multicolumn{9}{|l|}{ Experiment 2} \\
\hline Leaf blades & $297 b$ & $335 a$ & $328 b$ & $361 a$ & $330 \pm 20$ & 0.047 & 0.088 & 0.859 \\
\hline Stem + sheath & 540 & 498 & 530 & 526 & $523 \pm 19$ & 0.387 & 0.723 & 0.486 \\
\hline Dead material & $109 a$ & $118 a$ & $77 b$ & $81 b$ & $96 \pm 8.3$ & 0.629 & 0.029 & 0.887 \\
\hline Inflorescences & $55 \mathrm{ab}$ & $50 \mathrm{ab}$ & $64 a$ & $32 b$ & $50 \pm 8.2$ & 0.008 & 0.454 & 0.030 \\
\hline
\end{tabular}

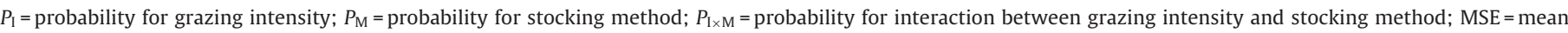
standard error.

Means followed by lowercase letters on line differ by Tukey test $(P<0.05)$.

$30^{\circ} \mathrm{C} \mathrm{min}^{-1}$ until $215^{\circ} \mathrm{C}$ waiting $1 \mathrm{~min}$ and $6^{\circ} \mathrm{C} \mathrm{min}^{-1}$ for $300^{\circ} \mathrm{C}$; $21 \mathrm{~min})$. The FID temperature was maintained at $340^{\circ} \mathrm{C}$. The GC procedure was calibrated with a standard external solution containing a mixture of synthetic $C_{7}$ to $C_{40}$ n-alkanes (>99\% purity, Sigma-Aldrich Corp., St. Louis, MO, USA) at concentrations similar to those found in the extract. The areas of the chromatographic peaks corresponding to each n-alkane were determined using the software Shimadzu GC Solution, where the identification of n-alkane chain length between $C_{20}$ to $C_{35}$ was based on comparison with an external standard, by the retention time average of $n$-alkane in the each column. The peaks identified were converted into amounts of n-alkanes taking the internal standard $\mathrm{C}_{34}$ as reference and calculated in $\mathrm{mg} \mathrm{kg}^{-1} \mathrm{DM}$ of feces and grass. The daily DMI was estimated from the ratio between the concentration of natural and dosed n-alkane $\left(C_{31}: C_{32}\right.$, respectively) obtained in samples of pasture and feces, according to the equation proposed by Mayes et al. (1986).

\subsection{Estimates of methane emission}

Daily $\mathrm{CH}_{4}$ emission was measured using the $\mathrm{SF}_{6}$ tracer technique reported by Johnson et al. (1994). The $\mathrm{SF}_{6}$ permeation tubes used in the experiment had an average permeation rate (PR) of $1.327 \pm 0.224 \mathrm{mg} \mathrm{day}^{-1}$ (Experiment 1 ) and $2.358 \pm 0.189 \mathrm{mg} \mathrm{day}^{-1}$ (Experiment 2) at the time of their deployment in the reticulum (per os dosing), and breath samples were collected after 10 days of tube deployment.

For this evaluation we used the same three animal testers as used for evaluating of DMI.

The air sampling system used stainless steel cylinders $(0.5 \mathrm{~L}$ volume) as sample collection device with sample flow regulated by a brass ball-bearing (Gere and Gratton, 2010). The cylinders were cleaned with high purity nitrogen gas $\left(\mathrm{N}_{2}\right)$ and pre-evacuated $(<0.5 \mathrm{mb})$ previous to each sample collection. The flow regulators were calibrated to allow a remaining vacuum in the canister of about $500 \mathrm{mb}$ at the end of the sample collection period (5 days). The inflow restrictor was located just above the animal's nostrils and protected against water and dust by means of a double filter. In addition to the 'breath' samples, background air samples were collected in triplicate, being placed about $1 \mathrm{~m}$ above ground level.

In Experiment 1, the collection of gas was carried out in the fourth stocking cycle. In Experiment 2, two collections were carried out, one in the third and another in the fourth stocking cycle. The periods of gas collection were chosen to be as close as possible to the evaluation period of DMI by the animals.
After the collection period, the pressure in each tube was measured and each sample was diluted with $\mathrm{N}_{2}$, and then measured again for the final pressure in the tube. Breath and background samples were analysed for concentrations of $\mathrm{CH}_{4}$ (ppm, parts per million by volume) and $\mathrm{SF}_{6}$ (ppt, parts per trillion by volume) by gas chromatography (Shimadzu 2010, Japan) using flame ionization $\left(250^{\circ} \mathrm{C}\right)$ and electron capture $\left(350^{\circ} \mathrm{C}\right)$ detectors, respectively. Three standards of $\mathrm{CH}_{4}$ and $\mathrm{SF}_{6}$ mixtures were used to calibrate the gas chromatograph and track its performance over a range of 5-20 ppm and $30-1000 \mathrm{ppt}$ for $\mathrm{CH}_{4}$ and $\mathrm{SF}_{6}$, respectively.

Estimates of emissions of $\mathrm{CH}_{4}$ using the tracer technique over the sample collection were calculated from the specific $\mathrm{PR}$ of $\mathrm{SF}_{6}$ and the $\mathrm{CH}_{4} \mathrm{SF}_{6}{ }^{-1}$ ratio of mixing ratios $(\mathrm{v} / \mathrm{v})$ in breath samples, after correction for background gas concentrations (Johnson et al., 1994). For this purpose $\mathrm{PR}$ of $\mathrm{SF}_{6}$ was expressed per day, consequently the emissions estimates corresponded to daily emissions.

\subsection{Statistical analysis}

Data were subjected to analysis of variance (ANOVA) at 5\% level of significance. Fixed effects included stocking methods, grazing intensities and the interaction between stocking methods and grazing intensities, and the blocks were random effects. For variables that were measured in each stocking cycle, this effect was included in the model as a repeated measure over time. The mean of three tester animals per paddock was the experimental unit used in the statistical analysis. When differences among treatments were detected, means were compared by the Tukey test $(P<0.05)$. Linear regressions were tested, the best model being defined by the highest coefficient of determination $\left(R^{2}\right)$ significant at $5 \%$ level $(P<0.05)$. The statistical package SAS version 9.3 (SAS Institute Inc., Cary, NC, USA, 2011) was used.

\section{Results}

\subsection{Sward characteristics}

The parameters related to morphological composition of the pasture showed an interaction $(P<0.05)$ between stocking methods and grazing intensities for stems + sheaths, dead material (Experiment 1) and inflorescences (Experiment 2). In Experiments 1 and 2, the leaf blade mass was greater at the moderate than low grazing intensity $(P<0.05)$, regardless of the stocking method. The mass of inflorescences (Experiment 1 ) was greater 
Table 2

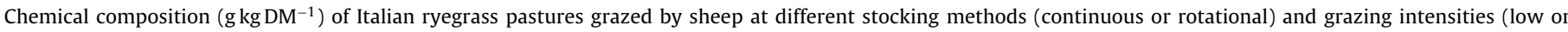
moderate), obtained by hand plucking.

\begin{tabular}{|c|c|c|c|c|c|c|c|c|}
\hline \multirow[t]{2}{*}{ Variables } & \multicolumn{2}{|c|}{ Continuous } & \multicolumn{2}{|c|}{ Rotational } & \multirow[t]{2}{*}{ Mean \pm MSE } & \multirow[t]{2}{*}{$P_{\mathrm{I}}$} & \multirow[t]{2}{*}{$P_{\mathrm{M}}$} & \multirow[t]{2}{*}{$P_{\mathrm{I} \times \mathrm{M}}$} \\
\hline & Low & Moderate & Low & Moderate & & & & \\
\hline \multicolumn{9}{|c|}{ Experiment 1} \\
\hline $\mathrm{OM}$ & $935 a$ & $931 b$ & $938 a$ & $928 b$ & $933 \pm 1.6$ & 0.027 & 0.857 & 0.299 \\
\hline $\mathrm{CP}$ & 138 & 141 & 118 & 127 & $131 \pm 4.5$ & 0.531 & 0.082 & 0.722 \\
\hline NDF & 586 & 606 & 606 & 613 & $603 \pm 4.5$ & 0.092 & 0.102 & 0.396 \\
\hline $\mathrm{ADF}$ & 302 & 311 & 326 & 318 & $314 \pm 4.1$ & 0.898 & 0.067 & 0.291 \\
\hline GE & 18.5 & 18.0 & 18.3 & 18.1 & $18.2 \pm 0.1$ & 0.303 & 0.796 & 0.710 \\
\hline \multicolumn{9}{|c|}{ Experiment 2} \\
\hline $\mathrm{OM}$ & $907 a$ & $910 a$ & $903 b$ & $895 b$ & $903 \pm 2.1$ & 0.307 & 0.006 & 0.065 \\
\hline $\mathrm{CP}$ & 188 & 213 & 208 & 189 & $199 \pm 7.5$ & 0.839 & 0.897 & 0.125 \\
\hline NDF & 483 & 474 & 475 & 476 & $476 \pm 7.6$ & 0.793 & 0.841 & 0.716 \\
\hline $\mathrm{ADF}$ & 251 & 239 & 253 & 255 & $249 \pm 4.9$ & 0.549 & 0.319 & 0.434 \\
\hline GE & $17.8 \mathrm{a}$ & $18.1 \mathrm{a}$ & $17.7 b$ & $17.6 \mathrm{~b}$ & $17.8 \pm 0.1$ & 0.549 & 0.030 & 0.084 \\
\hline
\end{tabular}

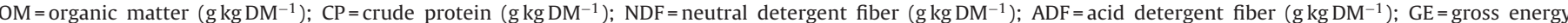

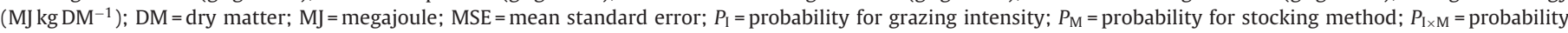
for interaction between grazing intensity and stocking method.

Means followed by lowercase letters on line differ by test $F(P<0.05)$.

at low than moderate grazing intensity $(P<0.05)$. In Experiment 2 , the mass of stems + sheaths did not differ between treatments $(P>0.05)$, while the mass of dead material was greater in the continuous than rotational stocking method $(P<0.05)$ (Table 1).

Regarding the chemical composition of the pasture (Table 2), there was no interaction between stocking methods and grazing intensities $(P>0.05)$. OM was greater for low than moderate grazing intensity in Experiment 1, and greater for continuous than rotational stocking in Experiment $2(P<0.05)$. CP, NDF, $\mathrm{ADF}$ and GE (Experiment 1) and $\mathrm{CP}, \mathrm{NDF}$ and ADF (Experiment 2 ) did not differ between treatments $(P>0.05)$. In Experiment $2 \mathrm{GE}$ was greater for continuous than rotational stocking $(P<0.05)$.

Sward characteristics and production of Italian ryegrass were similar for both years of assessment (Experiments 1 and 2) (Table 3). Only SH presented interaction $(P<0.05)$ between stocking method and grazing intensities (Experiments 1 and 2 ). There was an effect $(P<0.05)$ of grazing intensity on actual HA, HM and residual HM (Experiments 1 and 2). Actual HA was close to the target proposed for treatments. However, the THP did not differ between treatments (Experiments 1 and 2) $(P>0.05)$, with an average of $8320 \pm 371 \mathrm{~kg}$ DM ha ${ }^{-1}$ in Experiment 1 and $8738 \pm 198 \mathrm{~kg} \mathrm{DM} \mathrm{ha}^{-1}$ in Experiment 2 .

\subsection{Animal performance}

There was no interaction between stocking methods and grazing intensities $(P>0.05)$ for any variable of animal performance (Table 4). The SR showed similar response in the two years of assessment (Experiments 1 and 2), represented by the effect of grazing intensity, with greater SR at moderate than low grazing intensity, regardless of the stocking method. Lamb ADG was greater $(P<0.05)$ for continuous than rotational stocking, regardless of grazing intensity (Experiments 1 and 2). On the other hand, ewe ADG measured in Experiment 2 did not differ between treatments. The LWGHA had the same response for both experiments ( 1 and 2 ), represented by the effect of grazing intensity, with greater LWGHA in moderate than in low grazing intensity $(P<0.05)$.

\subsection{Dry matter intake and methane emission}

There was no interaction between stocking methods and grazing intensities $(P>0.05)$ for DMI and methane emission variables (Table 5). In Experiment 1, DMI was greater for sheep on continuous than rotational stocking, while DMI in Experiment 2 was similar for all treatments $(P>0.05)$, with an average of $1673 \pm 83 \mathrm{~g}$ animal $^{-1} \mathrm{day}^{-1}$. Emission of $\mathrm{CH}_{4}$ did not differ $(P>0.05)$

Table 3

Variables of Italian ryegrass pasture grazed by sheep with different stocking methods (continuous or rotational) and grazing intensities (low or moderate).

\begin{tabular}{|c|c|c|c|c|c|c|c|c|}
\hline \multirow[t]{2}{*}{ Variables } & \multicolumn{2}{|c|}{ Continuous } & \multicolumn{2}{|l|}{ Rotational } & \multirow[t]{2}{*}{ Mean \pm MSE } & \multirow[t]{2}{*}{$P_{\mathrm{I}}$} & \multirow[t]{2}{*}{$P_{\mathrm{M}}$} & \multirow[t]{2}{*}{$P_{\mathrm{I} \times \mathrm{M}}$} \\
\hline & Low & Moderate & Low & Moderate & & & & \\
\hline \multicolumn{9}{|l|}{ Experiment 1} \\
\hline Actual HA & $17.2 \mathrm{a}$ & $9.0 \mathrm{~b}$ & $17.5 \mathrm{a}$ & $9.7 b$ & $13.4 \pm 0.7$ & 0.003 & 0.373 & 0.580 \\
\hline $\mathrm{SH}$ & $21.5 b$ & $15.0 d$ & $24.6 a$ & $20.8 c$ & $20.3 \pm 0.1$ & $<0.001$ & $<0.001$ & $<0.001$ \\
\hline HM & $2581 a$ & $1698 b$ & $2538 a$ & $2005 b$ & $2255 \pm 123$ & 0.011 & 0.161 & 0.087 \\
\hline THP & 8961 & 6658 & 8537 & 8573 & $8321 \pm 372$ & 0.129 & 0.295 & 0.119 \\
\hline Residual HM & 3829a & $3062 b$ & $3618 a$ & 2871b & $3344 \pm 177$ & 0.017 & 0.448 & 0.069 \\
\hline \multicolumn{9}{|l|}{ Experiment 2} \\
\hline Actual HA & $18.1 \mathrm{a}$ & $10.3 b$ & $16.5 a$ & $9.9 b$ & $13.7 \pm 0.6$ & $<0.001$ & 0.082 & 0.248 \\
\hline $\mathrm{SH}$ & $20.6 b$ & $14.9 \mathrm{c}$ & $22.7 a$ & $20.5 b$ & $19.8 \pm 0.1$ & $<0.001$ & $<0.001$ & $<0.001$ \\
\hline HM & $2732 a$ & $2008 b$ & 2943a & $2445 b$ & $2532 \pm 121$ & 0.011 & 0.120 & 0.564 \\
\hline THP & 9046 & 8687 & 8979 & 8242 & $8738 \pm 199$ & 0.217 & 0.548 & 0.656 \\
\hline Residual HM & $3327 a$ & $2203 b$ & $3400 a$ & $3040 b$ & $2992 \pm 193$ & 0.017 & 0.104 & 0.162 \\
\hline
\end{tabular}

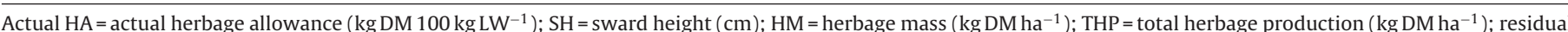

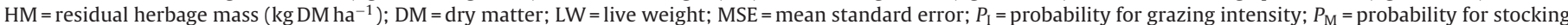
method; $P_{\mathrm{I} \times \mathrm{M}}=$ probability of interaction between grazing intensity and stocking method.

Means followed by lowercase letters on line differ by Tukey test $(P<0.05)$. 
Table 4

Performance variables for sheep grazing Italian ryegrass with different stocking methods (continuous or rotational) and grazing intensities (low or moderate).

\begin{tabular}{|c|c|c|c|c|c|c|c|c|}
\hline \multirow[t]{2}{*}{ Variables } & \multicolumn{2}{|c|}{ Continuos } & \multicolumn{2}{|c|}{ Rotational } & \multirow[t]{2}{*}{ Mean \pm MSE } & \multirow[t]{2}{*}{$P_{\mathrm{I}}$} & \multirow[t]{2}{*}{$P_{\mathrm{M}}$} & \multirow[t]{2}{*}{$P_{\mathrm{I} \times \mathrm{M}}$} \\
\hline & Low & Moderate & Low & Moderate & & & & \\
\hline \multicolumn{9}{|c|}{ Experiment 1} \\
\hline SR & $888 b$ & 1091a & $833 b$ & $1346 a$ & $1039 \pm 64$ & 0.010 & 0.262 & 0.097 \\
\hline ADG & $152 \mathrm{a}$ & $148 a$ & $103 b$ & $76 b$ & $121 \pm 7.7$ & 0.387 & 0.029 & 0.235 \\
\hline LWGHA & $397 b$ & $556 a$ & $336 b$ & $468 a$ & $428 \pm 32$ & 0.005 & 0.064 & 0.677 \\
\hline \multicolumn{9}{|c|}{ Experiment 2} \\
\hline SR & $921 b$ & $1243 a$ & $1016 \mathrm{~b}$ & $1485 a$ & $1166 \pm 47$ & 0.001 & 0.067 & 0.729 \\
\hline $\mathrm{ADG}_{\text {ewes }}$ & 25.8 & -11.0 & -18.6 & -13.6 & $-4.3 \pm 9.4$ & 0.411 & 0.249 & 0.296 \\
\hline $\mathrm{ADG}_{\text {lambs }}$ & $240 \mathrm{a}$ & $243 a$ & $225 b$ & $193 b$ & $225 \pm 7.9$ & 0.107 & 0.010 & 0.063 \\
\hline LWGHA & $395 b$ & $565 a$ & $461 b$ & $582 a$ & $500 \pm 33$ & 0.029 & 0.397 & 0.599 \\
\hline
\end{tabular}

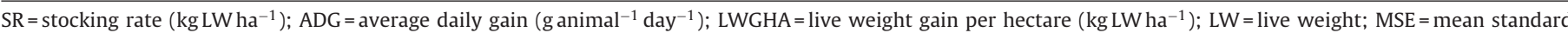
error; $P_{\mathrm{I}}=$ probability for grazing intensity; $P_{\mathrm{M}}=$ probability for stocking method; $P_{\mathrm{I} \times \mathrm{M}}=$ probability for interaction between grazing intensity and stocking method.

Means followed by lowercase letters on line differ by $F$ test $(P<0.05)$.

between treatments in Experiments 1 and 2, with a mean of $22.7 \pm 1.0$ and $39.9 \pm 1.3 \mathrm{~g} \mathrm{CH}_{4}$ animal $^{-1}$ day $^{-1}$, respectively.

Methane production ( $\mathrm{g} \mathrm{kg} \mathrm{DMI}^{-1}$ and gross energy intake (\% GEI)) did not differ between treatments in Experiment $1(P>0.05)$, while in Experiment 2 these parameters were greater for continuous than rotational stocking $(P<0.05)$, regardless of grazing intensity. In both experiments daily methane emitted per unit area was affected by grazing intensity, with greater rates in moderate than in low grazing intensity, while daily emission per ADG was greater in rotational than in continuous stocking, regardless of grazing intensity $(P<0.05)$ (Table 5$)$.

\section{Discussion}

Low grazing intensity (HA between 3 and 4 times the potential daily DMI) means approximately $66-75 \%$ of the pasture is not consumed (Jamieson and Hodgson, 1979). This, in turn, reflects a change in the proportion of morphological components of the plant, contributing to more stem and less leaf (Table 1) with consequent depression in LWGHA (Table 4). The level of DMI, the quality of diet and food processing, among other factors, can influence the emission of $\mathrm{CH}_{4}$ (Johnson and Johnson, 1995). Thus, considering the similarity in chemical composition of the forage in both experiments, a linear relationship between DMI and $\mathrm{CH}_{4}$ emissions per animal (Fig. 1) was observed. This pattern of response was previously described by Lassey et al. (1997) with sheep, Kurihara et al. (1999) with cattle and Hammond et al. (2013) studying with sheep in a respiration chamber. Pinares-Patiño et al. (2003b) also found a positive relationship between the intake of digestible NDF and the emission of $\mathrm{CH}_{4}\left(\mathrm{~g}_{\text {animal }}{ }^{-1} \mathrm{day}^{-1}\right.$ ) of sheep with results from respiration chamber (leucaena hay) and pasture (perennial ryegrass/white clover).

Data from literature suggests sheep emissions can vary from 12.2 to $37.3 \mathrm{~g} \mathrm{CH}_{4}$ animal $^{-1}$ day $^{-1}$ (Sun et al., 2012; Hammond et al., 2011; Ulyatt et al., 2005; Pinares-Patiño et al., 2003a; Ulyatt et al., 2002; Pelchen and Peters, 1998), depending on pastures and animal categories. In fact, Ulyatt and Lassey (2001) indicate that approximately $87 \%$ of the variation in $\mathrm{CH}_{4}$ emission is between animals, suggesting the high variability of $\mathrm{CH}_{4}$ emission data being due to individual animal variations. In this study, $\mathrm{CH}_{4}$ emission varied between 17-33 and 20-55 $\mathrm{g} \mathrm{CH}_{4}$ animal $^{-1}$ day $^{-1}$ (Experiments 1 and 2, respectively).

When the emission of $\mathrm{CH}_{4}$ was transformed to $\mathrm{g} \mathrm{CH}_{4} \mathrm{DMI}^{-1}$, there was better standardization of data, since the daily emission per animal was variable. This response provided a comparison with different types and species of animals, where values between 13.8 and $27.0 \mathrm{~g} \mathrm{CH}_{4} \mathrm{~kg} \mathrm{DMI}^{-1}$ were described by various authors (Ulyatt et al. (2002) and Pedreira et al. (2009) for lactating cows; Hulshof

Table 5

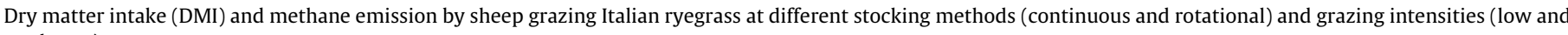
moderate).

\begin{tabular}{|c|c|c|c|c|c|c|c|c|}
\hline \multirow[t]{2}{*}{ Variables } & \multicolumn{2}{|c|}{ Continuous } & \multicolumn{2}{|c|}{ Rotational } & \multirow[t]{2}{*}{ Mean \pm MSE } & \multirow[t]{2}{*}{$P_{\mathrm{I}}$} & \multirow[t]{2}{*}{$P_{\mathrm{M}}$} & \multirow[t]{2}{*}{$P_{\mathrm{I} \times \mathrm{M}}$} \\
\hline & Low & Moderate & Low & Moderate & & & & \\
\hline \multicolumn{9}{|l|}{ Experiment 1} \\
\hline \multicolumn{9}{|l|}{ DM intake } \\
\hline g animal ${ }^{-1}$ day $^{-1}$ & 1369a & $1322 a$ & $1244 b$ & $907 \mathrm{~b}$ & $1210 \pm 71$ & 0.110 & 0.035 & 0.210 \\
\hline \multicolumn{9}{|l|}{$\mathrm{CH}_{4}$ emission } \\
\hline g animal $^{-1}$ day $^{-1}$ & 24.5 & 22.7 & 23.7 & 20.7 & $22.7 \pm 1.0$ & 0.298 & 0.531 & 0.794 \\
\hline $\mathrm{g} \mathrm{kg} \mathrm{DMI}^{-1}$ & 19.5 & 19.3 & 19.5 & 19.5 & $19.5 \pm 0.4$ & 0.945 & 0.979 & 0.912 \\
\hline$\%$ GEI & 5.9 & 5.5 & 5.9 & 6.0 & $5.8 \pm 0.2$ & 0.757 & 0.587 & 0.699 \\
\hline $\mathrm{kg} \mathrm{ha}^{-1}$ day $^{-1}$ & $0.66 b$ & $0.85 a$ & $0.67 b$ & $0.88 \mathrm{a}$ & $0.74 \pm 0.1$ & 0.018 & 0.784 & 0.865 \\
\hline $\mathrm{g} \mathrm{kg} \mathrm{ADG}^{-1}$ day $^{-1}$ & $183 b$ & $159 b$ & $240 a$ & $285 a$ & $220 \pm 17$ & 0.562 & 0.001 & 0.091 \\
\hline \multicolumn{9}{|l|}{ Experiment 2} \\
\hline \multicolumn{9}{|l|}{ DM intake } \\
\hline g animal $^{-1}$ day $^{-1}$ & 1477 & 1629 & 1563 & 1919 & $1674 \pm 84$ & 0.143 & 0.272 & 0.548 \\
\hline \multicolumn{9}{|l|}{$\mathrm{CH}_{4}$ emission } \\
\hline g animal $^{-1}$ day $^{-1}$ & 41.7 & 41.2 & 38.7 & 38.8 & $39.9 \pm 1.3$ & 0.952 & 0.443 & 0.913 \\
\hline $\mathrm{g} \mathrm{kg} \mathrm{DMI}^{-1}$ & $27.7 \mathrm{a}$ & $26.7 a$ & $21.9 b$ & $19.3 b$ & $23.6 \pm 1.1$ & 0.398 & 0.013 & 0.682 \\
\hline$\%$ GEI & $8.6 a$ & $8.2 \mathrm{a}$ & $6.9 b$ & $6.1 \mathrm{~b}$ & $7.3 \pm 0.3$ & 0.351 & 0.017 & 0.826 \\
\hline $\mathrm{kg} \mathrm{ha}^{-1}$ day $^{-1}$ & $0.54 \mathrm{~b}$ & $0.80 a$ & $0.64 b$ & $1.0 \mathrm{a}$ & $0.76 \pm 0.1$ & 0.007 & 0.114 & 0.590 \\
\hline $\mathrm{g} \mathrm{kg} \mathrm{ADG}^{-1}$ day $^{-1}$ & $164 b$ & $178 b$ & 189a & $215 a$ & $190 \pm 6.6$ & 0.092 & 0.016 & 0.619 \\
\hline
\end{tabular}

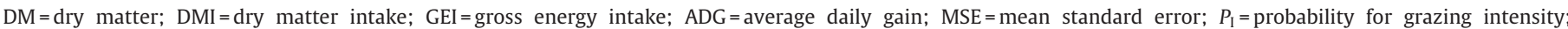
$P_{\mathrm{M}}=$ probability for stocking method; $P_{\mathrm{I} \times \mathrm{M}}=$ probability of interaction between grazing intensity and stocking method.

Means followed by lowercase letters on line differ by $F$ test $(P<0.05)$. 
et al. (2012) and Beauchemin et al. (2007) for beef cattle; Ulyatt et al. (2002) for lactating ewes; Hammond et al. (2013), Ulyatt et al. (2005) and Sun et al. (2012) in male sheep; Puchala et al. (2005) for goats). According to Lassey et al. (1997) and Hammond et al. (2013), there is a negative association between DMI ( $\left.\mathrm{g}_{\text {animal }}{ }^{-1} \mathrm{day}^{-1}\right)$ and the emission of $\mathrm{CH}_{4}\left(\mathrm{~g} \mathrm{CH}_{4} \mathrm{~kg} \mathrm{DMI}^{-1}\right)$. This fact was evidenced in both experiments (Fig. 2).

A very important factor regarding the efficiency of utilization of DMI by the animal is the flow of energy loss during food digestion by ruminants. Lassey (2007) concluded that even when high quality forage ( $75 \%$ digestibility) is consumed, only $58 \%$ of GEI by the animal is transformed into net energy. The remainder is lost in feces (25\%) in the form of $\mathrm{CH}_{4}(6 \%)$, in urine (6\%) and in the form of heat (5\%). Johnson and Ward (1996) mentioned that these losses in the form of $\mathrm{CH}_{4}$ could vary between 2 and $15 \%$, which agrees with GE losses between 3.5 and 7.5\% reported in different sheep categories (Ulyatt et al., 2005; Pinares-Patiño et al., 2003a, b; Ulyatt et al., 2002; Pelchen and Peters, 1998). Similar values were found in this study (Table 5).

This study confirms that $\mathrm{CH}_{4}$ emission by ruminants is a result of individual animal production (Tables 4 and 5). Greater efficiency found in continuous stocking can be associated with ingestive behavior of animals, considering that animals may manifest greater diet selection with this stocking method (Briske et al., 2008).

Differences in sward structure due to grazing intensity were also found (Table 4), although the observed difference in ADG was more related to stocking method than grazing intensities. In a classic study, Poppi et al. (1987) reported that DMI is maximized by lambs on pasture with $\mathrm{HM}$ of approximately $1800 \mathrm{~kg} \mathrm{DM} \mathrm{ha}^{-1}$. In all treatments, and in both experiments, HM was greater or similar to that value, which leads to the conclusion that performance of lambs was not limited by this variable. Barbosa et al. (2007) studied the performance of lambs grazing on Italian ryegrass, and found the same response for ADG (183 and $154 \mathrm{~g} \mathrm{animal}^{-1} \mathrm{day}^{-1}$, for continuous and rotational stocking, respectively).

Results indicated greater $\mathrm{CH}_{4}$ emission per area for moderate grazing intensity (19.9 and $20.7 \mathrm{~kg} \mathrm{CO}_{2}$ eqv. ha ${ }^{-1}$ day $^{-1}$ in Experiments 1 and 2, respectively) than in low grazing intensity (15.2 and $13.6 \mathrm{~kg} \mathrm{CO}_{2}$ eqv. ha ${ }^{-1}$ day $^{-1}$ in Experiments 1 and 2, respectively). However, a fairer manner to compare systems would consider $\mathrm{CH}_{4}$ emission per $\mathrm{kg}$ of animal product produced (Cottle et al., 2011). Phetteplace et al. (2001) registered values of 8.4, 6.4 and $1.3 \mathrm{~kg} \mathrm{CO}_{2}$ eqv. $\mathrm{ADG}^{-1}$ for beef cows, grazing cattle after weaning and feedlot cattle, respectively. In this study grazing sheep was more efficient. The registered values were $3.9 \mathrm{kgCO}_{2}$ eqv. $\mathrm{ADG}^{-1}$ for continuous stocking and $6.0 \mathrm{~kg} \mathrm{CO}_{2}$ eqv. $\mathrm{ADG}^{-1}$ for rotational stocking in Experiment 1, and $3.9 \mathrm{~kg} \mathrm{CO}_{2}$ eqv. $\mathrm{ADG}^{-1}$ for continuous stocking and $4.7 \mathrm{~kg} \mathrm{CO}_{2}$ eqv. $\mathrm{ADG}^{-1}$ for rotational stocking in Experiment 2. Rotational stocking in $\mathrm{CH}_{4}$ by gain was 35 and $15 \%$ greater than with continuous stocking method (Experiments 1 and 2 , respectively).

These results have two meanings for ICLS planning. Considering the pasture phase and the different options to explore livestock production, results suggest that a more favorable $C$ balance of the whole system might be achieved by producing sheep than cattle. In the same sense, continuous stocking management would allow for a more efficient production per unit $\mathrm{CO}_{2}$ eqv. emitted, than rotational stocking. However, to reach this final output, it is obviously necessary to assess the others gases involved and the crop phase.

Integrated systems differ from crop production systems due to the presence of the grazing animal, which influences dynamics of soil nutrients (Doran, 2002). Part of the nutrients consumed by animals is transferred back to the soil in the form of feces and urine (Hirata et al., 2011), which influences dynamics of soil organic matter (Carran and Theobald, 2000). Souza et al. (2009) pointed out that sound grazing management (sward heights greater than $20 \mathrm{~cm}$ ) of annual temperate pastures (Italian ryegrass + oat) succeeding soybean promoted an increase in soil total organic $C$, particulate organic $\mathrm{C}$, total $\mathrm{N}$ and particulate organic matter. Adequate grazing management and soil cover are necessary to reach those benefits, as mentioned by Matsuoka et al. (2003). In this context, HM is a determinant to the sustainability of the whole system, and grazing management again determines this amount. According to Denardin and Kochhann (1993), an annual addition of $6000 \mathrm{~kg} \mathrm{ha}^{-1}$ of biomass residues on soil surface is necessary to maintain soil C stocks in no-till systems. Considering this target, all grazing treatments were presumably successful as $C$ sinks, as the average pasture production was $8321 \pm 371$ and $8738 \pm 198 \mathrm{~kg} \mathrm{DM} \mathrm{ha}^{-1}$ for Experiments 1 and 2, respectively. Notwithstanding, HM at the end of the stocking cycle is also important, as it represents the stockpiled biomass that is fundamental to the no-till crop in succession. Except for the moderate grazing intensity with continuous stocking in Experiment 2, residual HM was around $3000 \mathrm{~kg} \mathrm{ha}^{-1}$, which can be considered a good amount of soil cover (Souza et al., 2009) to favor the maintenance of a sound soil environment.

\section{Conclusions}

Stocking method was more important than grazing intensity in determining methane production by grazing sheep. Continuous stocking was the most efficient grazing management in reducing methane emissions per unit animal production.

\section{Acknowledgements}

The research leading to these results has been conducted as part of the Animal Change project which received funding from the European Community's Seventh Framework Programme (FP7/2007-2013) under the grant agreement no. >266018, from National Council Scientific Development (CNPq) and PECUS/Embrapa Research Network.

\section{References}

AOAC, 1975. Official Methods of Analysis, 12th ed. Association of Official Analytica Chemists, Washington, DC, USA

Barbosa, C.M.P., Carvalho, P.C.F., Cauduro, G.F., Kunrath, T.R., Gianluppi, G.D.F., 2007. Terminação de cordeiros em pastagens de azevém anual manejadas em diferentes intensidades e métodos de pastejo. Braz. J. Anim. Sci. 36, 1953-1960 (in Portuguese).

Barthram, G.T., 1985. Experimental techniques: the HFRO sward stick. In: The Hill Farming Research Organization Biennial Report 1984/1985. HFRO, Penicuik, pp. 29-30.

Beauchemin, K.A., McGinn, S.M., Martinez, T.F., McAllister, T.A., 2007. Use of condensed tannin extract from quebracho trees to reduce methane emission from cattle. J. Anim. Sci. 85, 1990-1996.

Briske, D.D., Derner, J.D., Brown, J.R., Fuhlendorf, S.D., Teague, W.R., Havstad, K.M., Gillen, R.L., Ash, A.J., Willms, W.D., 2008. Rotational grazing on rangelands: reconciliation of perception and experimental evidence. Range. Ecol. Manage. 61 $3-17$.

Carvalho, P.C.F., Anghinoni, I., Moraes, A., Souza, E.D., Sulc, R.M., Lang, C.R., Flores, J.P.C., Lopes, M.L.T., Da Silva, J.L.S., Conte, O., Wesp, C.L., Levien, R., Fontaneli, R.S., Bayer, C., 2010. Managing grazing animals to achieve nutrient cycling and soil improvement in no-till integrated systems. Nutr. Cycl. Agroecosyst. 88, 259-273 (Dordrecht).

Carran, R.A., Theobald, P.W., 2000. Effects of excreta return on properties of a grazed pasture soil. Nutr. Cycl. Agroecosys. 56 (2), 79-85 (Bonn).

Cottle, D.J., Nolan, J.V., Wiedemann, S.G., 2011. Ruminant enteric methane mitigation: a review. Anim. Prod. Sci. 51, 491-514.

Denardin, J.E., Kochhann, R.A., 1993. Requisitos para implantacão e a manutencão do sistema plantio direto. In: EMBRAPA, Plantio direto no Brasil. Aldeia Norte, Passo Fundo, pp. 474, 19-27 (in Portuguese).

Doran, J.W., 2002. Soil health and global sustainability: translating science into practice. Agric. Ecosyst. Environ. 88 (2), 119-127 (Amsterdam).

Dove, H., Mayes, R., 2006. Protocol for the analysis of n-alkanes and other plant-wax compounds and for their use as markers for quantifying the nutrient supply of large mammalian herbivores. Nat. Protoc. 1, 1680-1697.

Easley, J.F., McCall, J.T., Davis, G.K., Shirley, R.L., 1965. Analytical Methods for Feeds and Tissues. Nutrition Laboratory. Dept. of Animal Science, University of Florida, Gainesville, 81 pp. 
FAO, 2006. Livestock's Long Shadow. Environmental Issues and Options. Food and Agriculture Organization of the United Nations, Rome, Italy.

FAO, 2010. Integrated Crop-Livestock Systems for Sustainable Development. Plant Production and Protection Division Consultation Documents. Food and Agriculture Organization of the United Nations, Rome, Italy.

Franzluebbers, A.J., 2010. Achieving soil organic carbon sequestration with conservation agricultural systems in the Southeastern United States. Soil. Sci. Soc. Am. J. 74, 347-357 (Madison).

Gere, J.I., Gratton, R., 2010. Simple, low-cost flow controllers for time averaged atmospheric sampling and other applications. Latin Am. Appl. Res. 40, 377-381.

Hammond, K.J., Burke, J.L., Koolaard, J.P., Muetzel, S., Pinares-Patiño, C.S., Waghorn, G.C., 2013. Effects of feed intake on enteric methane emissions from sheep fed fresh white clover (Trifolium repens) and perennial ryegrass (Lolium perenne) forages. Anim. Feed Sci. Technol. 179, 121-132.

Hammond, K.J., Hoskin, S.O., Burke, J.L., Waghorn, G.C., Koolaard, J.P., Muetzel, S. 2011. Effects of feeding fresh white clover (Trifolium repens) or perennial ryegrass (Lolium perenne) on enteric methane emissions from sheep. Anim. Feed Sci. Technol. 166-167, 398-404.

Hirata, M., Higashiyama, M., Hasegawa, N., 2011. Diurnal pattern of excretion in grazing cattle. Livest. Sci. 142 (1-3), 23-32 (Amsterdam).

Holland, J.M., 2004. The environmental consequences of adopting conservation tillage in Europe: reviewing the evidence. Agric. Ecosyst. Environ. 103, 1-25.

Hulshof, R.B.A., Berndt, A., Gerritis, W.J.J., Dijkistra, J., van Zijderveld, S.M., Newbold, J.R., Perdok, H.B., 2012. Dietary nitrate supplementation reduces methane emission in beef cattle fed sugarcane-based diets. J. Anim. Sci. 90, 2317-2323.

Intergovernmental Panel on Climate Change - IPCC, 2007. United Nations Environment Programme. Assessment Report 4: Contribution of Working Groups I, II and III to the Fourth Assessment Report of the Intergovernmental Panel on Climate Change. Geneva.

Jamieson, W.S., Hodgson, J., 1979. The effects of variation in sward characteristics upon the ingestive behaviour and herbage intake of calves and lambs under a continuous stocking management. Grass Forage Sci. 34, 273-282.

Johnson, A.D., 1978. Sample preparation and chemical analisys of vegetation. In: Manejte, L.T. (Ed.), Measurement of Grassland Vegetation and Animal Production. Commonweath Agricultural Bureax, Aberustwysth, pp. 96-102.

Johnson, K., Huyler, M., Westberg, H., Lamb, B., Zimmerman, P., 1994. Measurement of methane emissions from ruminant livestock using a sulfur hexafluoride tracer technique. Environ. Sci. Technol. 28, 359-362.

Johnson, K.A., Johnson, D.E., 1995. Methane emissions from cattle. J. Anim. Sci. 73 2483-2492.

Johnson, K.A., Ward, G.M., 1996. Estimates of animal methane emissions. Environ. Monit. Assess. 42, 133-141.

Klingman, D.L., Miles, S.R., Mott, G.O., 1943. The cage method for determine consumption and yield of pasture herbage. Agron. J. 35, 739-746.

Kurihara, M., Magner, T., Hunter, R.A., McCrabb, G.J., 1999. Methane production and energy partition of cattle in the tropics. Brit. J. Nutr. 81, 227-234.

Lassey, K.R., 2007. Livestock methane emission: from the individual grazing animal through national inventories to the global methane cycle. Agric. Forest. Meteorol. 142, 120-132.

Lassey, K.R., Ulyatt, M.J., Martin, R.J., Walker, C.F., Shelton, I.D., 1997. Methane emis sions measured directly from grazing livestock in New Zealand. Atmos. Environ. 31, 2905-2914.

Matsuoka, M., Mendes, I.C., Loureiro, M.F., 2003. Biomassa microbiana e atividade enzimática em solos sob vegetação nativa e sistemas agrícolas anuais e perenes na região de Primavera do Leste (MT). Rev. Bras. Cienc. Solo, Viçosa 27 (3) 425-433 (in Portuguese)

Mayes, R.W., Lamb, C.S., Colgrove, P.M., 1986. The use of dosed and herbage nalkanes as markers for the determination of herbage intake. J. Agric. Sci. 107 $161-170$.
Mott, G.O., Lucas, H.L., 1952. The design, conduct, and interpretation of grazing trials on cultivated and improved pastures. In: International Grassland Congress, Pennsylvania, 1952, pp. 1380-1385 (proceedings).

National Research Council - NRC, 1985. Nutrient Requirements of Sheep, 6th ed. Washington: National Academic of science, $99 \mathrm{pp}$.

Pedreira, M.S., Primavesi, O., Lima, M.A., Frighetto, R., Oliveira, S.G., Berchielli, T.T. 2009. Ruminal methane emission by dairy cattle in Southeast Brazil. Sci. Agric 66, 742-750.

Pelchen, A., Peters, K.J., 1998. Methane emissions from sheep. Small Ruminant Res. 27, 137-150.

Phetteplace, H.W., Johnson, D.E., Seidl, A.F., 2001. Greenhouse gas emissions from simulated beef and dairy livestock systems in the United States. Nutr. Cycl. Agroecosys. 60, 99-102.

Pinares-Patiño, C.S., Ulyatt, M.J., Lassey, K.R., Barry, T.N., Holmes, C.W., 2003a. Persistence of differences between sheep in methane emission under generous conditions. J. Agric. Sci. 140, 227-233.

Pinares-Patiño, C.S., Ulyatt, M.J., Waghorn, G.C., Lassey, K.R., Barry, T.N., Holmes, C.W. Johnson, D.E., 2003b. Methane emission by alpaca and sheep fed on Lucerne hay or grazed on pastures of perennial ryegrass/white clover or birdsfoot trefoil. J. Agric. Sci. 140, 215-226.

Pontes, L.S., Nabinger, C., Carvalho, P.C.F., Trindade, J.K., Montardo, D.P., Santos, RJ 2003. Variáveis morfogênicas e estruturais de Azevém Anual (Lolium multiflorum Lam.) manejado em diferentes alturas. Braz. J. Anim. Sci. 32, 814-820 (in Portuguese).

Poppi, D.P., Hughes, T.P., L'huillier, P.J., 1987. Intake of pasture by grazing ruminants. In: Nicol, A.M. (Ed.), Livestock Feeding on Pasture. New Zealand Society of Animal Production, pp. 55-64.

Puchala, R., Min, B.R., Goetsch, A.L., Sahlu, T., 2005. The effect of a condensed tannincontaining forage on methane emission by goats. J. Anim. Sci. 83, 182-186.

Smith, P., Martino, D., Cai, Z., Gwary, D., Janzen, H., Kumar, P., McCarl, B., Ogle, S. O'Mara, F., Rice, C., Scholes, B., Sirotenko, O., Howden, M., McAllister, T., Pan, G. Romanen, V., Scheneider, U., Towprayoon, S., 2007. Policy and technological constraints to implementation of greenhouse gas mitigation options in agriculture. Agric. Ecosyst. Environ. 118, 6-28 (Amsterdam).

Souza, E.D., Costa, S.E.V.G.A., Anghinoni, I., Carvalho, P.C.F., Andrigueti, M., Cao, E. 2009. Estoques de carbono orgânico e de nitrogênio no solo em sistema de integração lavoura-pecuária em plantio direto, submetido a intensidades de pastejo. Rev. Bras. Cienc. Solo 33, 1829-1836 (in Portuguese).

Sun, X.Z., Hoskin, S.O., Zhang, G.G., Molano, G., Muetzel, S., Pinares-Patiño, C.S., Clark, H., Pacheco, D., 2012. Sheep fed forage chicory (Cichorium intybus) or perennial ryegrass (Lolium perenne) have similar methane emissions. Anim. Feed Sci. Technol. 172, 217-225.

Ulyatt, M.J., Lassey, K.R., 2001. Methane emissions from pastoral systems: the situation in New Zealand. Arch. Latinoam. Prod. Anim. 9 (1), 118-126.

Ulyatt, M.J., Lassey, K.R., Shelton, I.D., Walker, C.F., 2005. Methane emission from sheep grazing four pastures in late summer in New Zealand. N. Z. J. Agric. Res. 48, 385-390.

Ulyatt, M.J., Lassey, K.R., Shelton, I.D., Walker, C.F., 2002. Methane emission from dairy cows and wether sheep fed subtropical grass-dominant pastures in midsummer in New Zealand. N. Z. J. Agric. Res, 45, 227-234.

United States Department of Agriculture (USDA), 1999. Soil Taxonomy. A Basic System of Soil Classification for Making and Interpreting Soil Surveys (USDA, 1-871) Washington DC.

Van Soest, P.J.; Robertson, J.B., 1985. Analysis of Forages and Fibrous Foods - A Laboratory Manual for Animal Science. Ithaca.

Wims, C.M., Deighton, M.H., Lewis, E., O’Loughlin, B., Delaby, L., Boland, T.M., O'Donovan, M., 2010. Effect of pre-grazing herbage mass on methane production, dry matter intake, and milk production of grazing dairy cows during the mid-season period. J. Dairy Sci. 93, 4976-4985. 